\title{
Place-Making of Ecotourism in Tasik Chini: From Exploratory to the Contemporary Biosphere Reserve
}

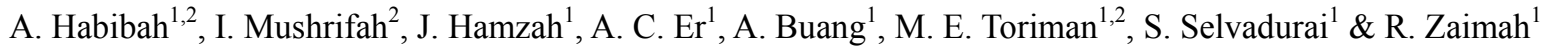 \\ ${ }^{1}$ School of Social, Development and Environmental Studies, Faculty of Social Sciences and Humanities, \\ Universiti Kebangsaan Malaysia, Malaysia \\ ${ }^{2}$ Tasik Chini Research Centre, Faculty of Science and Technology, Universiti Kebangsaan Malaysia, Malaysia \\ Correspondence: A. Habibah, School of Social, Development and Environmental Studies, Faculty of Social \\ Sciences and Humanities, Universiti Kebangsaan Malaysia, 43600 Bangi, Malaysia. E-mail: ha@ukm.my; \\ habibahahmad2012@gmail.com
}

Received: March 14, 2013 Accepted: April 11, 2013 Online Published: April 28, 2013

doi:10.5539/ass.v9n6p84 URL: http://dx.doi.org/10.5539/ass.v9n6p84

\begin{abstract}
Place-making is crucial in tourism destination as how it evolves and develops over time plays a significantly role in destination's sustainability. As ecotourism is often perceived as an excellent tool for promoting sustainable development, including in the Biosphere Reserve (BR), any initiatives in promoting this destination, therefore, have to be in a responsible manner, representing a real experience of the destination. While there is copious of literature on ecotourism in the BRs, no research has been conducted on how place-making of ecotourism in Tasik Chini from its evolution to the current status of Biosphere Reserve. Taking into account the needs of place-making that fits the aspiration of a sustainable destination, this article aims to analyze how place-making of Tasik Chini evolved and being developed in the life cycle of Tasik Chini as an ecotourism destination, aiming at tracing on travel engagement and ecotourism experiences. The study reveals four major components that drive the place-making of ecotourism in Tasik Chini, from exploratory to contemporary towards achieving sustainable development: the state of ecotourism in the BR, who the segments are, involvement of community and the government intervention and support system. It is imperative an integrated place-making of ecotourism destination be promoted and enhanced by all stakeholders in the future undertaking.
\end{abstract}

Keywords: place-making, ecotourism, life cycle, local involvement, Tasik Chini biosphere reserve

\section{Introduction}

Place-making is one of the strategies often employed when a destination intends to position itself in the international tourism arena and at the same time, seeks a balance between conservation and development in order to achieve a sustainable ecotourism destination. This is however, a big challenge when a destination is facing a declining stage and on other hand, is recognized as a 'protected and designated area' including the Biosphere Reserves (BR). Nevertheless many scholars claim that with a concerted effort been given to the place-making of a destination; with a real experience been portrayed and staged to the tourists, repeat visitation of tourists to the destination will be assured (Gunn, 1994; Canter, 1977; Potteiger et al., 1998; Pratiwi et al., 2010).

Moreover, ecotourism is often perceived as an excellent tool in seeking a balance between local livelihood and conservation of protected areas or designated areas (Weaver, 1999; Lai \& Nepal, 2006; Gurung \& Seeland, 2008; Campbell, 1999; Honey, 2008) while the Biosphere reserve on the hand, is an area exhibiting three functional roles in conservation, development and logistic support in learning and research (UNESCO, 2012, 2007). This means that both the ecotourism and the biosphere reserves aim to achieve sustainable development. In fact, the underlying basis why ecotourism fits well within the BRs lies in its similarity in managing natural resources, respect local community and fostering sustainable development (Kušová et al., 2008; Lu \& Deng, 2008; Van Mai \& Bosch, 2010).

Of the 553 Biosphere Reserves in 107 countries around the world in 2013, much has been written on their initiatives in local participation in ecotourism practices and development (Kušová et al., 2007; Buckley, 2007; Goslings, 1999; Stronza \& Gordillo, 2008; Honey, 2008; Batisse, 1997; García-Frapolli et al., 2008; Bonheur \& Lane, 2002). However, efforts comprehending on how these sites are constructed and promoted as an ecotourism 
destination, beginning from its evolution, development, stagnation and decline period until they had achieved success, are rarely demonstrated. Hence, an assessment of the past as well as its recent place-making of ecotourism destination is an essential undertaking.

Similar to any other BRs, Tasik Chini is endorsed as the pioneer Biosphere Reserve in Malaysia in 2009 aims to achieve a sustainable ecosystem, including positioning itself as a sustainable ecotourism destination. Rich in tropical biodiversity, it is one of the ecotourism spot for more than three decades (Habibah et al., 2010, 2012, 2011). In the 2000s, there was a drastic drop of tourists arrival, While the previous studies assert on the unplanned land development within surrounding areas jeopardizing the ecotourism richness and ecotourists' flows (Habibah et al., 20120b), little is known on the capacity of the place-making of Tasik Chini as an ecotourism destination that may have influenced and determined the destination life cycle, ranging from exploration, development to a declining as well as rejuvenation stage.

As the place-making is crucial in ensuring continuous tourist arrivals, what have the tourism providers - be they the tourism governance, the community and the tourists contribute to the place-making of this destination. What is more pertinent within the realm of sustainable ecotourism, at this juncture, i) what makes a place-making of Tasik Chini as an ecotourism destination ii) who and what shape ecotourism experiences in Tasik Chini Biosphere Reserve? Against this backdrop, an assessment of evolution and development of place-making of Tasik Chini will provide a basis for sustainable representation of a destination, mutually agreed among stakeholders, especially the host community, the government and the tourists. This article, therefore aims at evaluating how place-making of ecotourism emerged from the past to present Tasik Chini Biosphere Reserve (TCBR).

\section{Literature Review on Ecotourism, Biosphere Reserve and Place-Making}

\subsection{Ecotourism and Biosphere Reserve}

Ecotourism: Since the introduction of ecotourism, there is no one mutually agreed definition (Honey, 2008; Campbell, 1999; Fennell, 2001; Blangy \& Mehta 2006; Horwich, 2003). The first eco-tourism definition was coined by Ceballos-Lascurain (1991: 25) as travelling [to] relatively undisturbed or uncontaminated areas with the specific objective of studying, admiring, and enjoying the scenery and its wild plants and animals, as well as any existing cultural manifestations (both past and present) found in these areas. More recent definitions advocate that it should: improve local welfare, contribute positively to visitor's satisfaction, and incorporate environmental education (The International Ecotourism Society, 2005; Blangy \& Mehta, 2006; Honey, 2008).

Biosphere Reserve: The Biosphere reserves are defined by the MAB-UNESCO as areas of terrestrial and coastal ecosystems promoting solutions to reconcile the conservation of biodiversity with its sustainable use. They are internationally recognized, nominated by national governments and remain under sovereign jurisdiction of the states where they are located. Each of the BR comprises three zones; core, buffer and transitional zones, intending to fulfil three integrated and mutually reinforced functions in conservation, development and logistic support in learning and research (UNESCO $(2012,2007)$. During the United Nations Decade of Education for Sustainable Development (UNDESD 2004-2013), biosphere reserves are given full responsible to function as learning laboratories or learning sites which emphasized on evidence-based knowledge, iterative principles and collaborative initiatives to achieve sustainable development (Ishwaran et al., 2008). Consequently, the BRs generate distinctive learning communities not limiting to the locals residing within the areas but extending the opportunities to the international communities.

Moreover, innovative approaches such as social learning (McCarthy et al., 2006; Cruz et al., 2005), ecosystem approach (Flitner, 2006), system thinking approach (Nguyen et al., 2009) and sustainable landscape (Kušová et al., 2007) provide a pool of alternative knowledge and tools that can be introduced to foster sustainable development. The literature and official reports of Biosphere reserves define BR as the sites of special area of special people (Schultz et al., 2011; Schianetz et al., 2007, 2009; UNESCO, 2012; Habibah et al., 2012a) and many were involved and actively promoting ecotourism.

All the above mentioned achievements denote more and more responsibility that the BRs have to execute to the society. Taking into account the nature of the Biosphere reserve ecosystem existence, ecotourism is therefore fundamental to the Biosphere reserve in order to exhibit their roles and functions in conservation, development and learning as well as creating sustainable region (Boucher et al., 2003, Ishwaran et al., 2008; Kriesel, 2011; Stoll-Kleemann \& Welp, 2008; Khelghat-Doost et al., 2011; Habibah et al., 2012b).

\subsection{Destination Life Cycle}

The "destination life cycle", a term introduced in Butler's model (1980), has become very influential in tourism. 
The model suggests that each stage of cycle has implications on the tourist flows, relationship between hosts and guests, the degree of change in the destination and the involvement of external stakeholders (Swarbrooke, 1999). He established six stages namely exploration, investment, development, consolidation, stagnation. Stagnation can further progress into decline, rejuvenation or continued stagnation. While a destination passes through each stage, the evolution factors become more and more complicated, and according to Cooper et al. (1998), is depended on the following indicators: the amount of current development, form of development (mass tourism, alternative forms), investments, demand trends, planning, policy and management, governmental policy, accessibility of the destination, impacts from tourism and competitive destinations.

Introduced by the Butler life cycle in the 1980s, the idea expands to become more relevant to the destination planning and development. With a series of evolution, exploration, development and stable as well as declining and rejuvenation period, In a product life cycle, tourism infrastructure and facilities are also key attractions in satisfying the eco-tourists' needs. This explicitly positioned the provision of ecotourism facilities comprising the accommodation, recreation and learning experiences with nature and culture of the locals. Over time as the destination develops and matures, it is expected that these facilities will be adequately furnished, sustained and of high quality. Instead, among destinations that have experienced stagnation and decline, quality facilities are seldom guaranteed.

More crucial, studies on how destinations seek to revitalise after experiencing stagnation and decline are rare and fragmented. Several authors somehow assert on the Butler life cycle in demonstrating the evolution and achievement of the ecotourism destination (Butler, 1980, 2011; Agarwal, 2006), and of recent one, the introduction of 3Cs of a destination; context, character and consequences (Pornphol et al., 2010). Butler (2011) also points out that successful rejuvenation requires a complete change of the attraction on which tourism is based. According to him, only two strategies have been successful:1) the addition of man-made attractions or 2) the use of untapped natural resources. As a complete reorientation of a destination might be not feasible due to financial or political constraints, Agarwal (2006) suggests an alternative "reorientation stage" where efforts for renewal takes place at the destination.

Many of the studies assert on the components that need to be reviewed include types of ecotourism products ranging from soft to hard or active to passive, larger to a smaller scale and from leisure to experiential seeking purposes and motivations. As many of these venues or sites are located in remote areas within which rich in biological diversity and indigenous cultures (Lai \& Nepal, 2000; Badola et al., 2012; Lu \& Deng, 2008), ecotourism will not exist without a healthy and attractive physical environment; tranquil, stable, equitable social environment; and educated group of tourists and locals motivated to support measures to protect local environment and culture (Goslings, 1999; Blangy \& Mehta, 2006: Honey, 2008; Zhang \& Lei, 2012). Therefore, one important standpoint that determines the effectiveness of the revitalising approach is the market priorities during the rejuvenation period, and equally important, is to know the ecotourists' needs, satisfaction and experiences they seek for (de la Barre, 2005; Kerstetter et al., 2004; Wallance, 1993; Kriesel 2011).

Relevant to the revitalising stage is the degree that the ecotourism development is improving the ecosystem where it stands and exhibits. In this vein, choosing an appropriate approach from 'minimalist' to 'enhancement' serves to actively improve on the environmental status quo through measures such as habitat rehabilitation, ecologically sensitive site hardening, and the acquisition of land for inclusion in high order protected area networks (Schultz et al., 2011; Kay, 1999). As often assert that ecotourism helps the poor and marginalised people of the rural and remote areas, engagement of the locals during the rejuvenation period is a must in terms of sustainable development (Honey, 2008; Horwich, 1993; Ezebilo, 2010). In a simple meaning, engaging them in the revitalizing process is the key focal practice. However, whilst Pretty's ladder of participation provides the understanding and mode of participation, studies also suggest a better choice is the implementation of the community driven participation compared to the community based participation (Coria \& Calfucura, 2012; Buss, 2012). This is because, the former, provides a balance between participation and collaboration, as ideas, views and inputs are derived from both, locals and related stakeholders.

\subsection{Place-Making of a Destination}

Place-making is defined as making sense of a place in the views of the stakeholders' vision, strategies and practices and as simple of an individual sense or construct of a destination or their experience. To the practitioners and tourism industry, place-making is a process of adding value and meaning to the public realm through community-based revitalization projects rooted in local values, history, culture, and the natural environment. Several scholars assert place-making or creating a sense of place in building an identity for the attraction (Gunn, 1994; Canter, 1977; Potteiger et al., 1998). In tourism, place-making is one of the strategies 
aimed to make tourists return to the destination that they have visited. Place-making arises from one experience or collective experiences that being passed through various mediums to prospective tourists.

While diverse meanings of place-making exist in the literature, differ on stakeholders' perspectives is also profound in the tourism production system. Generally place-making can be divided into host-guest, as stressed by Smith (1995). From the host perspectives, place-making is usually a construct of attractions that the communities can display and offer. Pratiwi et al.'s study on rural ecotourism assert on the two formal and informal ways of place-making of a destination (Pratiwi et al., 2010). From the guests' perspective, on the other hand, place-making often means a construct of place that tourists would like to experience and gaze. Whether with the economic or leisure factors, place-making has evolved and transmitted by visitors, with or without their intention. With regular visits to these areas, place-making is becoming a crucial means that not only the media have played their roles, but all tourism providers exhibit and serve what has been imagined and expected by the tourists.

Also obvious, place-making from the tourist perspective has been receiving more attention recently, especially on the insights of the real meanings of their experiences. Writing or narrative description based on their visits showed how significant can they be in making a return or first timer visits. According to recent studies, place-making from the tourist's perspective helps to promote destinations in favouring their individual taste markedly compared to the masses of the tourist segment and actual supply of tourism provision.

The tourists who have visited ecotourism sites highly valued conservation efforts and more importantly, minimized resources exploitation, respected the community's cultural tradition and supported value chain of the local economy (Kerstetter et al., 2004; Chaminuka et al., 2012; Habibah et al., 2012a). With this aspiration and practices, it is therefore crucial to ensure a real and sustainable place-making of ecotourism is materialized, especially among the stakeholders, be they the tourism providers, host as well as the ecotourists themselves.

From the tourism production, place-making of a destination can be visualised as touristic products. Taking the place-making of Clanwilliam as touristic product (Norten, 2011), tourist product is formed by the business actors comprising the three projects, and other attractions in town, like the village museum, small tourist businesses and the Rooibos factory. These projects, however, are not seen by the locals as a tourist attraction of their own. The local community instead, have their own focus area depending on their knowledge, experience and networks.

With the above mentioned literatures, in this study, place-making of a destination is a construct of experiences and products that the community, the tourism providers and stakeholders offer while it is the activities that the ecotourists experience during their visitation.

\section{Methods}

\subsection{Study Area}

Tasik Chini, located in the southeast region of the state of Pahang is also the second largest natural fresh-water lake in Malaysia. As the Biosphere reserve, Tasik Chini encompasses three interrelated functions and zonation; core, buffer and transitional zones. The designated area is rich in wetlands biodiversity, and ecological capitals. Tasik Chini is also home to the Jakun tribe, one of the major aborigines' groups in Malaysia. Residing in and within the surrounding area of the watershed, the Jakun forms a total six kampungs (small villages). Altogether 80 families or approximately 500 members stay in this sensitive area (Habibah et al., 2012a, 2011). The mainstay economy is mainly forest-based and agriculture-based activities. Tasik Chini, is one of earliest pristine ecotourism destinations in the early 70s. Popular with the iconic lotus plant spreading throughout the watershed, unplanned development and flood hazard are some of the human interventions causing impacts to the community.

\subsection{Data Collection and Analysis}

This study used a mixed method approach comprising a content analysis of the secondary resources of data and information as well as in-depth interviews with key respondents in the community in $2009-2013$. The study sets to analyze the place-making of Tasik Chini as an ecotourism destination, particularly on how Tasik was constructed as an ecotourism destination. Taking a Butler's idea (1980s) that a destination evolved in a life cycle, it began with its an introduction, exploration and development until recent development, especially in tracing the place-making of Tasik Chini from the ecotourists' views, the aboriginals' and the travel engagement, ecotourism approaches and revitalization initiatives. Therefore in this research, the progression of the place-making of Tasik Chini was divided into two major phase, the place-making from its evolution to development and second phase the contemporary era especially in 2009 -2013. Taking into account the needs of data collection representing these stages, several resources data were utilized. The following resources were gauged to derive the 
understanding of the exploration, introduction and recent development of Tasik Chini.

The secondary data referred were the national, regional state and local plans, including a proposed tourism area of forest reserve for public uses. The historical writings; geography and land use also help to uncover the ecotourism progression. Based on these secondary data, the place-making of Tasik Chini was analyzed how it was described in term of products, tourist demand and government and community involvement. On the other hand, the primary data provided details on the several aspects of community perspectives. The qualitative data, derived from in-depth interviews with the stakeholders of the locals, the focus group discussion and also a series of public consultation held by the research centre. Through this information, the authors were able to track similar aspects that have found in the earlier phase of the ecotourism development. The data collected were then analyzed descriptively, accordingly to the stages of destination lifecycle of Tasik Chini Biosphere reserve, ranging from its exploration to the contemporary era.

\section{Results and Discussions}

\subsection{Place-Making of Ecotourism: From Exploratory to the Rising of Ecotourism}

Tasik Chini is one of the ecotourism destinations in Malaysia. As a destination, Tasik Chini has a long history in place-making, believed to be in existence for more than three decades. It has been mentioned that ecotourism has started since early 1970s among the 'forest lovers' as an exploration to destinations that offer splendor of the forest, lake pristine and mystical experiences. In terms of developmental stages, by referring to its evolution in the early 1970s, Tasik Chini has surpassed more than three stages of the life cycle, evolution, introduction, development and stagnation, and therefore requires revitalization initiatives in place-making. Table 1 shows the evolution of Tasik until 2013.

Table 1. Evolution of ecotourism and progression, 1960s-2013

\begin{tabular}{|c|c|c|c|c|}
\hline $\begin{array}{lrr}\text { Evolution } & & \text { of } \\
\text { ecotourism } & \text { vs } & \text { time } \\
\text { scale } & & \end{array}$ & Past $1960,1970 s-1980 s$ & $1990-2000$ & $2001-2008$ & $2009-2013$ \\
\hline $\begin{array}{l}\text { Stage of ecotourism } \\
\text { with reference of } \\
\text { Butler tourist cycle }\end{array}$ & $\begin{array}{l}\text { Exploratory by the locals } \\
\text { and outsiders. English } \\
\text { and Indian as well as } \\
\text { locals. }\end{array}$ & $\begin{array}{l}\text { Booming as the } \\
\text { attraction }\end{array}$ & $\begin{array}{l}\text { Progressive but slowing } \\
\text { down }\end{array}$ & $\begin{array}{l}\text { Drastic Drops and } \\
\text { Gradually increasing }\end{array}$ \\
\hline Product & $\begin{array}{l}\text { Lake centric, not yet } \\
\text { recognized as ecotourism }\end{array}$ & $\begin{array}{l}\text { Lake and nature, } \\
\text { ecotourism }\end{array}$ & Ecotourism & Knowledge Ecotourism \\
\hline Local Involvement & Active with locals & Locals & Locals & $\begin{array}{l}\text { Local and collaboration } \\
\text { with Outsiders and Higher } \\
\text { education }\end{array}$ \\
\hline $\begin{array}{l}\text { Government } \\
\text { intervention }\end{array}$ & Low and forest reserve & $\begin{array}{l}\text { Tourism facilities } \\
\text { upgrading }\end{array}$ & $\begin{array}{l}\text { Conservation and regional } \\
\text { Ecer Development Plan - } \\
\text { environment } \\
\text { conservation }\end{array}$ & $\begin{array}{l}\text { Ecer development of Tasik } \\
\text { Chini, redevelopment of } \\
\text { tourist facilities }\end{array}$ \\
\hline Tourist arrivals & Small but progressing & Mass & Drops of mass tourist & $\begin{array}{l}\text { Special organized } \\
\text { academic and eco-tourist }\end{array}$ \\
\hline Lake nature & pristine & $\begin{array}{l}\text { Starting to having } \\
\text { environmental } \\
\text { problems }\end{array}$ & Dying state and slow death & $\begin{array}{l}\text { Towards conservation and } \\
\text { preservation }\end{array}$ \\
\hline
\end{tabular}

In the early days of its existence (that is in the late 1960s and early 1970s), there is no clear sign of ecotourism in Tasik Chini as mostly being recognized as 'the travel to undisturbed area'. The attractions were just simply the original wilderness of fishing; hunting and forest collecting. Among the visitors, magnificent scene of the blooming lotuses in June to September was often highlighted as the unforgettable experiences. Although there is no actual ecotourism business transaction as understood and practiced by the mass ecotourism in the late 1990s. What actually has occurred was a barter exchange of ecotourism in food stuffs and cigars for servicing the 'outsiders' their forest experiences. 
In the 1980s, significant numbers of domestic and international tourists visited Tasik Chini for its pristine nature. During that time, some local community saw this opportunity, hence, were motivated to provide basic accommodation in bed and breakfast, boatman, craftsmen and local guide. According to our key respondents, international tourists came through Sungai Pahang, and deal with the local tours who actually serve them the boatman. Although they have not received any formal trainings as tour guide, their keen interests in ecotourism have made them visible and popular among tourists.

In the late 1980s, the DARA, a regional development agency has undertaken a study that aimed at promoting Tasik Chini as one of the tourism destination. With an increasing demand of ecotourism as the pulling factor for development, Tasik Chini has been identified as in the state park of which the function was to become an ecotourism destination. Apart from the natural ambience, the socio-cultural environment and livelihood of the aborigines have become the major attraction. Tasik Chini enters into a rapid development stage when the ecotourism has also flourished and popularized as the alternative to mass tourism in the early 1990s. Due to commoditization of ecotourism during that time, more tourist infrastructures were developed. One of the key developments is the weir or barrage, which later claimed to be the causal of lake ecosystem disturbance resulting a drastic drop in tourist arrivals.

\subsubsection{The Place-Making of Tasik Chini from the Ecotourists' and Ecotourism Production's Perspective}

As mentioned that ecotourism is hardly recognized in the olden days, ecotourist is also facing similar situation; hardly a typology of tourist among those who travelled to this destination. In the early 70 s, travelers are those who only knew the hidden attraction of lake and virgin forest. This has a close tie with the nature lovers and the mystique wonders of Tasik Chini. Most of them travelled on an individual basis while those who travelled with tour agencies; normally flock from the tourism belt located in the tourism clusters, especially the Cherating tourism belt and the capital city of Kuala Lumpur.

During those days, the international tourists stayed for several days in the tribe settlement to explore the virginity of forest and lake attraction. Also apparent, their involvement with local livelihood was based on the understanding of exchange between goods and guided tour that they offered. Besides experiencing the pristine undisturbed area, they also seek outside aids to help the aborigines to venture new accommodation business.

The term eco-tourist as often cited as travelers who explored an undisturbed area by the ecotourism scholars is quite a recent phenomenon in Tasik Chini. Still facing limited accessibility, in the 1990s, most eco-tourists get through to this destination by crossing the Pahang River. Their entry-exit point was from the Kg Belimbing. Many of the tourists mentioned that while they had to push their boat during the low tide of water level, the enjoyment of these activities is one of the most memorable often cited. They spend time in the forest for nature enthusiasm and wanders.

\subsubsection{The Aboriginals' Place-Making}

The place-making of Tasik Chini from the locals' perspectives can be tracked in the early 1960s. Although the aboriginal is considered a small community and nomadic, often moved from one area to another, staying temporary and establishing some tracks in the roaming areas as their nature of livings provide a basis for travel or escapes to this area. In fact, interest to have a settlement with the proper mainstay economy and livelihood among the Jakuns, indirectly introduces tourism to this area. These initiatives came from the three families of Pak Alok (father of Awang, the current batin, i.e., chief), Pak Laksa (who ventured into tourism), and Pak Tempek (possess super natural powers), later, founded Kampung Gumum as their permanent residence. They planted rubber trees and fruit trees in the area around Laut Gumum. Under the Aborigines Settlement Scheme, 10 houses were supplied in 1977, and under the Low Cost Housing Scheme, 3 houses in 1993 and 5 houses in 2007. About 60 families live in Kampung Gumum, a number of them with their own field of rubber trees. The fruit trees are still relevant, not just for the fruit but also to keep track of ownership of pieces of land. The landscape of attraction during that stage also portrayed on the unique attraction of Tasik Chini and it continued to expand in the 1970s.

In the $80 \mathrm{~s}$, there seemed a small number of accommodations, nevertheless the locals managed to involve as the entrepreneurs in accommodation sector. According to our key respondent, during those days, she managed her small Kijang Emas which was once popular among the international backpackers. Her involvement in accommodation sector was motivated by the opportunities to meeting international tourists. Besides Norhayati as the only female aboriginal entrepreneur, several key players also dealt with tourists' services. The recent Tok Batin mentioned, during his young age, he was also involved in the tour guide services. His motivation was to share his skills in forest excursion, besides knowing better his forest. Although the forest roaming was naturally part of their culture, the needs to gaze and empower the forest route and the lake ecosystem were not easily 
obtained. He had to learn and practices, therefore through direct involvement in ecotourism; these skills are well adored and preserved. The package deals included the trail far to Bukit Tembakang, the highest landscape of Tasik Chini. Learning a 'survival' in the forest, cooking with the natural fire and explore the 'lauts' and rivers with kayaks provide the local construct of what ecotourism in Tasik Chini really means.

Interestingly, although men normally work in forest and the women take good care of their children and domestic needs, women were also involved actively in ecotourism. Our key respondent recalled her experiences in ecotourism; she started to adore forest excursion since she was still young. During her trips, survival skills included crafting of local plants' leaves as outdoor utensils and more importantly, traditional knowledge of herbal plants is also shared.

\subsubsection{The Government Intervention}

As mentioned in the evolutional destination studies that at the introductory stage of a destination are initialized by the locals, it seems the earlier development and offering of Tasik Chini also exhibited similar experiences. The government interference started when the destination had received an influx of ecotourism, especially in the late 1980s. The development of the weir was one of the physical developments introduced as a result of the commoditization. The weir, built in 1995, aimed to ensure the water level allows the cruising of the tourists who wished to explore both the lake and the river of Chini.

In terms of governance, several acts have been established, in response to the need of ensuring biodiversity. These mechanisms include federal legislation (Wildlife Act, 1972, Environmental Quality Act, 1974), provincial legislation Wildlife Act 1972, Fisheries Act 1985, Forestry Act 1984, Environmentally Quality Act 1974 (Act 127) \& Subsidiary Legislation, Land Rules Applicable to the States in Malaysia, and the Town and Country Planning Act, 1976) and management plans. All these show that the formal place-making of Tasik Chini is filled with rules and regulations, yet, it is not leading to a strong place-making of ecotourism destination. Even though Ecotourism National Plans was launch in 1996, Tasik Chini, somehow, was left out in the prioritization of ecotourism development program.

\subsection{The Present Ecotourism, 2001 - 2013}

Taking the establishment of Tasik Chini as the Biosphere reserve in 2009 to represent the current existence, ecotourism is now expected to be managed in sustainable manner. Ecotourism is the key responsible sector to ensure three major roles of BR comprising conservation, development and logistic functions. Therefore, it is expected the better place-making of ecotourism is constructed. However, as the data of tourist arrivals from 2007-2009 depicts a declining period of ecotourism, differ on stakeholders' views are also expected.

\subsubsection{Saving Tasik Chini: The Present Non and Organized Ecotourism}

It is well-accepted that as destination declines in attraction and service quality, the place-making of the destination will also decline. However, within the period of 2001 until 2013, an analysis of place-making from the present ecotourists showed two contradictory of place-making, negative and positive impression. The negative one was derived from the non-organized and organized tourist arrivals. It has noted that in the mid 2000s, more dissatisfaction were expressed as the lake ecosystem began to decline. Also through the social media, Tasik Chini needs to be saved as the national heritage. Although many reasons had been highlighted for the declining trend, lacking and poorly-managed lake environment somehow have diverted both locals and international tourists from this destination.

Added to this, many of the tourists' travel arrangements were organized by the tour agencies. Due to a declining ecosystem, many tour agencies refused to continue their travel itineraries and tour arrangements. Based on the scientific expedition organized by the Universiti Kebangsaan Malaysia in 2004, it has been found that a rapid change in land use was the major cause for declining quality of the environment. Encroachments of agriculture and mining as well as settlement put the pressure to the lake ecosystem. The concerns of 'saving a dying lake from disappearing' began to increase and have received public attention, both locals and internationals.

On the other hand, the positive views and impressions were derived from the knowledge ecotourists. The needs to fulfill the logistic functions have widened the learning experiences of the BR. As a result, the place-making of ecotourism is converging to a more responsible construct of a pro-environmental perspective. Among the knowledge ecotourism, conservation and rehabilitation programs need active participations from the prospective tourists.

\subsubsection{The Aboriginals' Place-Making}

As most of the Biosphere reserves aim at improving and providing sustainable livelihood of the locals, ensuring 
the locals' involvement in ecotourism is also attempted at Tasik Chini. As such, the local's perspective is encouraged in place-making of this destination. Simply, what locals possess should become the major attraction on offer. Based on the data collected in the fieldwork, the locals do contribute directly or indirectly in place-making of contemporary Tasik Chini. Some of the examples signify the rising role of the local community. Rajan Jones - an Indian man married to aboriginal women, offers chalet and tour since ecotourism is in its infancy. His passion in ecotourism and lake ecosystem is widespread as words of mouth for the international tourists. Nevertheless, he seemed worried of Tasik Chini fading out from the ecotourism site in the country. Meanwhile Pak Bahrin and Pak Ngah provide an array of Jakun's lifestyles at the settlement to visiting individual or group tourists. The only women entrepreneur, Mrs Norhayati, married to a local man, ventured into the chalet business with Kijang Emas in the 1990s also wishes to offer on her own chalet when we interviewed recently.

\subsubsection{Fashioning Ecotourism with Tourism Complexes and Services}

Being a tourism destination, ensuring quality facilities and services is the perquisite not to be taken for granted. With the fact that the existing facilities were not properly managed in the early $2000 \mathrm{~s}$, upgrading of the tourism infrastructures through the federal, the regional and state government funding were initiated, and Table 2 shows recent new facilities on offer.

Table 2. Tourism infrastructure and upgrading of facilities

\begin{tabular}{ll}
\hline Tourism facilities & Description \\
\hline Jetty & Main jetty for tourist movement and transfer \\
Resort in Tasik Chini & A total 18 room available in the core zone \\
Tourism Information centre & Information is open but still lack of update resources. \\
Tour agency and guide & No local tour agency available but only a local guide from the boatman \\
Restaurants & Available in the resort but with minimal choices of food and menus \\
Road & Road accessibility is far better in recent year. Three road access \\
\hline
\end{tabular}

Many more initiatives are planned in 2012 to 2025. With the strategic implementation plan acts as a guidance, tools and business plan, it is expected that ecotourism will be enhanced in two stages, a 'SAVE period' where programs will be centered to restoration. The conservation experiences such as plant a seed a day and lending hands for lotus should allure ecotourist experience. Besides ensuring a suitable range of tourist figure with the facilities available in the current situation, promotion and communication are encouraged. At the later stage, 2020-2025, the 'Enjoyment period' will be filled with thematic ecotourism themes will then be celebrated in the restored ecosystem.

\subsubsection{A Living Laboratory in Knowledge Ecotourism: Place-Making of University-Communities}

Unlike other ecotourism destination in Malaysia, Tasik Chini is also a living laboratory. With the collaboration between the University-Community, in particular with the Universiti Kebangsaan Malaysia, new labelling of knowledge ecotourism is suggested. As of 2013, more than 10 programs have been organized to cater various SAVE tourists (Scientist, Academic, Volunteer and Educational). The introduction of SAVE tourism is currently managed by the University as an ideal experiential learning. To ensure a balance of the community's involvement, the locals - young school children and the old generation were engaged directly in providing the socio-cultural experiences, including tour guiding, cultural performances, boatmen and events' facilitators. Although their involvement seems seasonal, these initiatives are given priority in the strategic implementation plans. Therefore with a living laboratory in place, a responsible place-making of Tasik Chini will be recreated in the near future.

\section{Conclusion}

This study revealed the evolution of ecotourism place-making of Tasik Chini. It began only as a small and remote pristine forest, followed with a development stage, aided with the promotion from the individual ecotourists. The ecotourism are forced into the commoditization system with the physical intervention, however, brought adverse impacts to the natural ecosystem. The contemporary period started when the site was endorsed as the Biosphere Reserve in 2009. In the light to have a balance place-making, Tasik Chini's experience showed 
that there is a need to introduce knowledge ecotourism, site refurbishment, diversifying of ecotourism experiences and aboriginal involvement. However, these initiatives should not be popularized as the top-down approach, but, as an integrated approach as they warrant the pro-active involvement of the stakeholders and the careful management of local resources. In fact, this study suggests that taking a historical evidence of the past to the present would help to build the sense of belonging of the community and at same time, guarantee a real and authentic tourists' experiences. It is also recommended that taking an in-sight of the place-making of the destination, beginning of its exploration to the contemporary era would signify a real Tasik Chini as a Biosphere Reserve.

\section{Acknowledgements}

The authors acknowledge grants received from the Ministry of Higher Education of Malaysia, entitled grant Lake Ecosystem Assessment of Tasik Chini (UKMTOPDOWN-ST-08-FRGS0003-2010) and Dana Lonjatan Penerbitan PM Dr Er Ah Choy, UKM-DLP-2012-030. The authors also thank all the key respondents, Tok Batin (the local headman) and Tasik Chini Research Centre for kind field assistance and support.

\section{References}

Agarwal, S. (2006). Coastal Resort Restructuring and the TALC. In R. W. Butler (Ed.), The Tourism Area Life Cycle: Conceptual and Theoretical Issues (pp. 201-218). Clevedon, UK, Channel View Publications.

Batisse, M. (1997). Biosphere reserves, a challenge for biodiversity conservation and regional development. Environment, 39(5), 7-33. http://dx.doi.org/10.1080/00139159709603644

Blangy, S., \& Mehta, H. (2006). Ecotourism and ecological restoration. Journal for Nature Conservation, 14, 233-236. http://dx.doi.org/10.1016/j.jnc.2006.05.009

Bonheur, N., \& Lane, B. D. (2002). Natural resources management for human security in Cambodia's Tonle Sap $\begin{array}{lllll}\text { Biosphere Reserve. Environmental Science \& } & \text { Policy, }\end{array}$ http://dx.doi.org/10.1016/S1462-9011(02)00024-2

Boucher, G., Conway, C., \& Der Meer, E. V. (2003). Tiers of engagement by universities in their region's development. Journal: Regional Studies, 37(9), 887-889. http://dx.doi.org/10.1080/0034340032000143896

Buss, D. (2007). Secret Destinations. Creativity or Conformity? Building Cultures of Creativity in Higher Education. A conference organised by the University of Wales Institute, Cardiff in collaboration with the Higher Education Academy. Cardiff January 8-10 2007. Retrieved June 14, 2012, from http://www.creativityconference07.org/presented_papers/Buss_Secret.doc

Butler, R. (1980). The concept of a tourist area of life cycle of evolution: implications for management of resources. Canadian Geographer, 19(1), 5-12. http://dx.doi.org/10.1111/j.1541-0064.1980.tb00970.x

Butler, R. W. (2011). Tourism Area Life Cycle. Contemporary Tourism Reviews. Series Editor: Chris Cooper. Goodfellow Publishers Limited, Woodeaton, Oxford. Retrieved from http://www.goodfellowpublishers.com

Barre, S. (2005). Learning Travel Product Development Workbook: A step-by-step guide for Yukon and Northern Entrepreneurs, North to Knowledge (N2K), Whitehorse, Yukon. Retrieved from http://www.tc.gov.yk.ca/pdf/LearningTravelProductDevelopmentWorkbook.pdf

Canter, D. V. (1977). The Psychology of Place. London: Architectural Press.

Cooper, C., Fletcher, J., Gilbert, D., \& Wanhill, S. (1998). Tourism: Principles and Practice. Essex: Pearson Education Limited.

Campbell, L. M. (1999). Ecotourism in rural developing communities. Annals of Tourism Research, 26(3), 534-553. http://dx.doi.org/10.1016/S0160-7383(99)00005-5

Cellabos-Lascurin, H. (1996). Ecotourism, Tourism and Protected Area. Gland: IUCN. http://dx.doi.org/10.2305/IUCN.CH.1996.7.en

Chaminuka, P. R., Groeneveld, A., Selomane, A. O., \& Van Ierland, E. C. (2012). Tourist preferences for ecotourism in rural communities adjacent to Kruger National Park: a choice experiment approach. Tourism Management, 33, 168-176. http://dx.doi.org/10.1016/j.tourman.2011.02.016

Coria, J., \& Calfucura, E. (2012). Ecotourism and the development of indigenous communities: The good, the bad, and the ugly. Ecological Economics, 73, 47-55. http://dx.doi.org/10.1016/j.ecolecon.2011.10.024

Cruz, R. E. H., Baltazar, E. B., Gomez, G. M., \& Lugo, E. I. J. E. (2005). Social adaptation ecotourism in the 
Lacandon Forest. Annals of Tourism Research, 32(3), 610-627. http://dx.doi.org/10.1016/j.annals.2004.08.005

Ezebilo, E. E. (2010). Community-based preferences for economic incentives to promote biodiversity conservation in a Tropical Rainforest. Int. J. Environ. Res., 4(3), 501-506.

Fennell, D. (2001). A content analysis of ecotourism definitions. Current Issues in Tourism, 4, 403-421. http://dx.doi.org/10.1080/13683500108667896

Flitner, M., Matthes, U., Oesten, G., \& Roeder, A. (Eds.). (2006). The ecosystem approach in forest biosphere reserves: results from three case studies. Albert-Ludwigs-Universität Freiburg, Freiburg.

Gunn, C. (1994). Tourism Planning: Basics, Concepts, Cases (3rd ed.). Washington, D.C.: Taylor \& Francis.

Gurung, D. H., \& Seeland, K. (2008). Ecotourism in Bhutan extending its benefits to rural communities. Annals of Tourism Research, 35(2), 489-508. http://dx.doi.org/10.1016/j.annals.2008.02.004

Habibah, A., Hamzah, J., Mushrifah, I., A. Buang, A., Toriman, M. E., \& Jusoff, K. (2011). The success factors of public consultation in the establishment of a Biosphere Reserve - evidence from Tasik Chini. World Applied Science Journal, 13, 74-81.

Habibah, A., Mushrifah, I., Hamzah, J., Toriman, M. E., Buang, A., Jusoff, K., Mohd Fuad, M. J., Er, A. C., \& Azima, A. M. (2012). Assessing natural capital for sustainable ecotourism in Tasik Chini Biosphere Reserve. Advances in Natural and Applied Sciences, 6(1), 1-9.

Habibah, A., Mohamed, R., Mushrifah, I., Hamzah, J., Aimi Syairah, M. N., \& Buang, A. (2012), Positioning University as knowledge ecotourism destination: key success factors. International Business Management, 6(1), 32-40. http://dx.doi.org/10.3923/ibm.2012.32.40

Habibah, A., Hamzah, J. \& Mushrifah, I. (2010). Sustainable livelihood of the community in tasik chini biosphere reserve: the local practices. Journal of Sustainable Development, 3(3), 184-196.

Honey, M. (2008). Ecotourism and Sustainable Development: Who Owns Paradise? (2nd ed.). Washington, DC: Island Press.

Horwich, R. H. (1993). Ecotourism and community development: A view from Belize. In K. Lindberg, \& D. Hawkins (Eds.), Ecotourism: A guide for planners and managers (pp. 152-168). North Bennington, VT: The Ecotourism Society.

Ishwaran, N., Persic, A., \& Tri, N. H. (2008). Concept and practice: the case of UNESCO Biosphere Reserves. $\begin{array}{llll}\text { Int. J. Environment and Sustainable Development, } & \text { 7(2), 118-131. }\end{array}$ http://dx.doi.org/10.1504/IJESD.2008.018358

Kay. J. J., Regier, H., Boyle, M., \& Francis, G. R. (1999). An ecosystem approach for sustainability: addressing the challenge of complexity. Futures, 31(7), 721-742. http://dx.doi.org/10.1016/S0016-3287(99)00029-4

Kerstetter, D. L., Hou, J. S., \& Lin, C. H. (2004). Profiling Taiwanese eco-tourists using a behavioral approach. Tourism Management, 25, 491-498. http://dx.doi.org/10.1016/S0261-5177(03)00119-5

Khelghat-Doost, H, Zainal Abidin Sanusi, Z. A., Tunku Fariddudin, T. F. F., \& Jegatesen, G. (2011). Institutions of higher education and partnerships in education for sustainable development: case study of the Regional Center of Expertise (RCE) Penang. Malaysia Journal of Sustainable Development, 4(3), 108-117.

Kušová, D., Těšitel, J., Matějka, K., \& Bartoš, M. (2008). Biosphere reserves-an attempt to form sustainable landscapes: a case study of three biosphere reserves in the Czech Republic. Landscape and Urban Planning, 84(1), 38-51. http://dx.doi.org/10.1016/j.landurbplan.2007.06.006

Kriesel, J. (2011). Education for sustainable development in the biosphere reserves Schaalsee, Germany, and Kristianstads Vattenrike, Sweden. Diploma thesis. University of Greifswald. Retrieved June 5, 2012, from http://www.mnf.unigreifswald.de/fileadmin/Geowissenschaften/geographie/angew_geo/Diplomarbeiten/Jan in_Kriesel_Diplomarbeit_BNE.pdf

Lai, P. H., \& Nepal, S. K. (2006). Local perspectives of ecotourism development in Tawushan Nature Reserve, Taiwan. Tourism Management, 27, 1117-1129. http://dx.doi.org/10.1016/j.tourman.2005.11.010

Lu, Y., \& Deng, J. (2008). The new environmental paradigm and nature-based tourism motivation. Journal of Travel Research, 46, 392-402. http://dx.doi.org/10.1177/0047287507308331

Lu, H., Campbell, D., Chen, J., Qin, P., \& Ren, H. (2007). Conservation and economic viability of nature reserves: An emergy evaluation of the Yancheng Biosphere Reserve. Biological Conservation, 139, 415-438. 
http://dx.doi.org/10.1016/j.biocon.2007.07.014

McCarthy, D., Whitelaw, G., Jongerden, P., \& Craig, B. (2006). Sustainability, social learning and the Long Point World Biosphere Reserve. Environments Journal, 34(2), 1-15.

Marzouki, M., Froger, G., \& Ballet, J. (2012) Ecotourism versus mass tourism. a comparison of environmental impacts based on ecological footprint analysis. Sustainability, 4, 123-140. http://dx.doi.org/10.3390/su4010123

Nguyen, N. C., Bosch, O. J. H., \& Maani, K. E. (2009). The Importance of systems thinking and practice for creating Biosphere Reserves as "learning laboratories for sustainable development". Retrieved from http://journals.isss.org/index.php/proceedings53rd/ article/view/1161/398

Notten, E. (2011). Tourism and place making in Clanwilliam, South Africa, Masters Thesis, Wageningen University, the Netherlands. Retrieved September 27, 2013, from http://edepot.wur.nl/164409

Pornphol, P., \& Mcgrath, G. M. (2010) Implementation of The tourism area life cycle model as an advisory decision support system centre for tourism and services research, Victoria University, Melbourne, Australia. Retrieved from http://www.pacis net.org/file/2010/P02-12.pdf

Pratiwi, W. D., Soedarmadji, N., \& Paramitha, Y. (2010). Place-making for tourism in rural settlements and the institutional collaboration Arte-Polis 3 International Conference on Creative Collaboration and the Making of Place, Retrieved January 25, 2013, from http://www.ar.itb.ac.id/wdp/wpcontent/uploads/2010/07/a081_wiwik_pratiwi_tourism_in_rural_settlement_ abstract.pdf

Schianetz, K, J., Tod, J., Kavanagh, L., Walker, P. A., Lockington, D., \& Wood, D. (2009). The practicalities of a learning tourism destination: A case study of the Ningaloo Coast. International Journal of Tourism Research, 11(6), 567-581. http://dx.doi.org/10.1002/jtr.729

Schianetz, K., Kavanagh, L., \& Lockington, D. (2007). The learning tourism destination: the potential of a learning organisation approach for improving the sustainability of tourism destinations. Tourism Management, 28(6), 1485-1496. http://dx.doi.org/10.1016/j.tourman.2007.01.012

Schultz, L., Duit, A., \& Folke, C. (2011). Participation, adaptive co-management, and management performance in the World Network of Biosphere Reserves. World Development, 39(4), 662-671. http://dx.doi.org/10.1016/j.worlddev.2010.09.014

Smith, S. (1995). Tourism Analysis: A Handbook (2nd ed.). Great Britain: Bookcraft (Bath) Ltd.

Stoll-Kleemann, S., \& O’Riordan, T. (2002). From participation to partnership in biodiversity protection: Experience from Germany and South Africa. Society \& Natural Resources, 15(2), 157-173. http://dx.doi.org/10.1080/089419202753403337

Stoll-Kleemann, S., \& Welp, M. (2008). Participatory and integrated management of biosphere reserves: lessons from case studies and a global survey. GAIA-Ecological Perspectives for Science and Society, 17, 161-168.

Swarbrooke, J. (1999). Sustainable Tourism Management. Wallingford, UK: CABI.

The International Ecotourism Society. (1990). The definition of ecotourism. Retrieved July 10, 2011, from http://www.ecotourism.org/index.htm

Tippett, J., Searle, B., Pahl-Wostl, C., \& Rees, Y. ( 2005). Social learning in public participation in river basin management - early findings from Harmoni COP European case studies. Environmental Science and Policy, 8, 287-299. http://dx.doi.org/10.1016/j.envsci.2005.03.003

UNESCO. (2012). The Man and the Biosphere (MAB) Programme. Retrieved July 1, 2011, from $\mathrm{http} / /$ www.unesco.org/new/en/natural-sciences/environment/ecological-sciences/man-and-biosphere-progra mme

UNESCO. (2007). UNESCO Biosphere Reserves: learning laboratories for sustainable development. Retrieved June 8, 2012, from http://unesdoc.unesco.org/images/0015/001516/151607e.pdf

Van Mai, T., \& Bosch, O. J. H. (2010). Systems thinking approach as a unique tool for sustainable tourism development: a case study in the Cat Ba Biosphere Reserve of Vietnam. Retrieved June 16, 2011, from http://www.systemdynamics.org/conferences/2010/proceed/.../P1312.pdf 
Wallance, G. N. (1993). Visitors management: lessons from Galapagos National Park. In K. Lindberg, \& D. Hawkins (Eds.), Ecotourism: A guide for planners and managers (pp. 55-81). North Bennington, VT: The Ecotourism Society.

Weaver, D. B. (2005). Comprehensive and minimalist dimensions of ecotourism. Annals of Tourism Research, 32(2), 439-455. http://dx.doi.org/10.1016/j.annals.2004.08.003

Zhang, H., \& Lei, S. L. (2012). A structural model of residents' intention to participate in ecotourism: The case of a wetland community. Tourism Management, 33, 916-925. http://dx.doi.org/10.1016/j.tourman.2011.09.012 